\title{
HESS Opinions "A perspective on isotope versus non-isotope approaches to determine the contribution of transpiration to total evaporation"
}

\author{
S. J. Sutanto ${ }^{1,2}$, B. van den Hurk ${ }^{1,3}$, P. A. Dirmeyer ${ }^{4}$, S. I. Seneviratne ${ }^{5}$, T. Röckmann ${ }^{1}$, K. E. Trenberth ${ }^{6}$, \\ E. M. Blyth ${ }^{7}$, J. Wenninger ${ }^{8,9}$, and G. Hoffmann ${ }^{1,10}$ \\ ${ }^{1}$ Institute for Marine and Atmospheric Research Utrecht (IMAU), University of Utrecht, Princetonplein 5, \\ 3584 CC Utrecht, the Netherlands \\ ${ }^{2}$ Research Center for Water Resources, Ministry of Public Works, J1. Ir. H. Djuanda 193, 40135 Bandung, Indonesia \\ ${ }^{3}$ KNMI, P.O. Box 201, 3730AE De Bilt, the Netherlands \\ ${ }^{4}$ George Mason University, 4400 University Drive, Mail Stop: 2B3, Fairfax, VA 22030, USA \\ ${ }^{5}$ Institute for Atmospheric and Climate Science, ETH Zurich, CHN N11, Universitätstrasse 16, 8092 Zurich, Switzerland \\ ${ }^{6}$ National Center for Atmospheric Research, P.O. Box 3000, Boulder, CO 80307, USA \\ ${ }^{7}$ Centre for Ecology and Hydrology, Wallingford, Oxfordshire, OX10 8BB, UK \\ ${ }^{8}$ UNESCO-IHE, Department of Water Engineering, P.O. Box 3015, 2601 DA Delft, the Netherlands \\ ${ }^{9}$ Delft University of Technology, Water Resources Section, P.O. Box 5048, 2600 GA Delft, the Netherlands \\ ${ }^{10}$ LSCE-Orme, point courier 129, CEA-Orme des Merisiers, 91 Gif-Sur-Yvette Cedex, France
}

Correspondence to: S. J. Sutanto (s.j.sutanto@uu.nl)

Received: 15 January 2014 - Published in Hydrol. Earth Syst. Sci. Discuss.: 5 March 2014

Revised: 25 June 2014 - Accepted: 25 June 2014 - Published: 4 August 2014

\begin{abstract}
Current techniques to disentangle the evaporative fluxes from the continental surface into a contribution evaporated from soils and canopy, or transpired by plants, are under debate. Many isotope-based studies show that transpiration contributes generally more than $70 \%$ to the total evaporation, while other isotope-independent techniques lead to considerably smaller transpiration fractions. This paper provides a perspective on isotope-based versus non-isotope-based partitioning studies. Some partitioning results from isotope-based methods, hydrometric measurements, and modeling are presented for comparison. Moreover, the methodological aspects of the partitioning analysis are considered, including their limitations, and explanations of possible discrepancies between the methods are discussed. We suggest sources of systematic error that may lead to biases in the results, e.g., instruments inaccuracy, assumptions used in analyses, and calibration parameters. A number of comparison studies using isotope-based methods and hydrometric measurements in the same plants and climatic conditions are consistent within the errors; however, models tend to produce lower transpiration
\end{abstract}

fractions. The relatively low transpiration fraction in current state-of-the-art land-surface models calls for a reassessment of the skill of the underlying model parameterizations. The scarcity of global evaporation data makes calibration and validation of global isotope-independent and isotope-based results difficult. However, isotope-enabled land-surface and global climate modeling studies allow for the evaluation of the parameterization of land-surface models by comparing the computed water isotopologue signals in the atmosphere with the available remote sensing and flux-based data sets. Future studies that allow for this evaluation could provide a better understanding of the hydrological cycle in vegetated regions.

\section{Introduction}

Continental evaporation (including transpiration, soil evaporation, and canopy evaporation) is an important process controlling energy and mass exchange between the terrestrial 
ecosystems and the atmosphere (Seneviratne et al., 2010). Transpiration is the largest contributor to the evaporation fluxes from continental areas (Lawrence et al., 2007; Blyth and Harding, 2011; Jasechko et al., 2013). Therefore, many studies have been carried out to quantify the transpiration fraction through direct measurements or techniques disentangling the various evaporation components. Direct measurement of transpiration has been performed for decades, but the accuracy and separation of transpiration from total evaporation still remain a challenge. The fraction of transpiration to the total evaporation flux obviously depends upon the nature and state-of-the-surface, such as the presence of lakes or the seasonality of vegetation (growing in the spring or dormant in autumn). These conditions generate variability in each evaporation component and complicate the separation of the various components.

There are many methods and techniques to quantify this transpiration fraction. A conventional method for partitioning evaporation is the combination of hydrometric measurements such as sap flow to measure transpiration rate with other methods to calculate total evaporation (Kelliher et al., 1992; Herbst et al., 1996; Roupsard et al., 2006; Mitchell et al., 2009; Cavanaugh et al., 2011). Soil evaporation is then calculated from the difference of total evaporation and transpiration with the assumption that canopy evaporation is a small component and can be neglected. More recent methods analyze the isotopic composition of liquid water and water vapor (e.g., Yepez et al., 2003; Ferretti et al., 2003; Williams et al., 2004; Xu et al., 2008; Lai et al., 2006; Robertson and Gazis, 2006; Wang et al., 2010; Sutanto et al., 2012; Jasechko et al., 2013). This method has become common since measurements of stable isotopologues in precipitation and water vapor are relatively easy and robust. Other methods use global land-surface models (Choudhury and DiGirolamo, 1998; Dirmeyer et al., 2006; Oleson et al., 2004). In the landsurface models, the contribution of each evaporation component is principally simulated from the land-surface scheme due to, for example, turbulent transfer, moisture limitations, and plant physiology. Although all methods above can estimate the transpiration fraction, results from these methods vary. In general, isotope-based methods tend to result in a higher transpiration fraction than other methods. Jasechko et al. (2013) estimated the global transpiration fraction to be 80-90\% of the total evaporation from land, which implies a more dominant role of transpiration than most other previous studies. The transpiration flux in that study was calculated using the isotope mass balance method in lake catchments where the isotopic composition of the evaporative flux was estimated using an evaporation model applied to the isotopic composition of the lake water.

Here we provide a perspective on the isotope-based method for isolating the contribution of transpiration to the total evaporation flux. As canopy evaporation is neglected in most isotope-based studies, we mainly discuss evaporation as a combination of transpiration and soil evaporation only. Some partitioning results from hydrometric measurements and modeling are presented for comparison. We also discuss briefly how the partitioning studies have been carried out, their limitations, and the possible causes of the discrepancies between those methods.

\section{Methods to derive the transpiration fraction of evaporation}

\subsection{Isotope-based method}

The use of stable water isotopologues (principally $\mathrm{H}_{2}^{18} \mathrm{O}$ and ${ }^{1} \mathrm{H}^{2} \mathrm{HO}$ ) as tracers present a new and important technique to enable flux tracing within the soil-plant-atmosphere continuum (SPAC) system (Kendall and McDonnell, 1998; Mook, 2000; Zhang et al., 2010; Wenninger et al., 2010). Processes like water diffusion and phase changes affect the partial pressures of the different water isotopologues. The lighter isotopologues preferentially evaporate from bare ground and open water surfaces such as oceans and lakes, and leave the condensate phase enriched in the heavier isotopologue. In contrast, transpiration does not modify the isotopic composition of the remaining groundwater since there is no isotopic fractionation during water uptake and transport in roots and stems (Ehleringer and Dawson, 1992; Kendall and McDonnell, 1998; Tang and Feng, 2001; Williams et al., 2004). This distinct isotopic difference makes water isotope analysis an interesting diagnostic for a quantitative separation between the evaporation flux from bare soils and open water on the one hand, and plant transpiration on the other hand. The isotopic composition of water is commonly expressed as a fractional difference relative to standard, noted as "delta $(\delta)$ " notation, usually given in per mill (\%o):

$\delta=\left(\left(R_{\text {sample }} / R_{\text {standard }}\right)-1\right)$.

For stable hydrogen isotopes, $R={ }^{2} \mathrm{H} /{ }^{1} \mathrm{H}$ is the deuteriumto-hydrogen ratio in sample, or in a standard usually Vienna Standard Mean Ocean Water (VSMOW).

Earlier studies to measure transpiration using stable isotope measurements have been carried out on eucalyptus trees by Calder et al. (1986, 1992) and Calder (1992). They injected deuterated water $(D)$ into tree roots and measured the transport of deuterium in stem water from roots to leaves as a tracer. Transpiration was calculated based on the total mass of tracer administered and the concentration in the stem water.

The isotope mass balance method is used to quantify the transpiration fraction. This method is based on a simple twosource mixing model, where evaporation $\left(F_{\mathrm{ET}}\right)$ is a sum of soil evaporation $\left(F_{\mathrm{E}}\right)$ and transpiration $\left(F_{\mathrm{T}}\right)$ :

$F_{\mathrm{ET}}=F_{\mathrm{T}}+F_{\mathrm{E}}$

where $F$ denotes a flux and subscript ET stands for evaporation, $T$ for transpiration and $E$ for soil evaporation. When 
each flux has its characteristic isotopic composition $\delta$, the isotopic mass balance is

$F_{\mathrm{ET}} \delta_{\mathrm{ET}}=F_{\mathrm{T}} \delta_{\mathrm{T}}+F_{\mathrm{E}} \delta_{\mathrm{E}}$

Transpiration and soil evaporation fluxes can be derived from Eq. (3) according to Zhang et al. (2010):

$F_{\mathrm{E}}=\frac{\delta_{\mathrm{T}}-\delta_{\mathrm{ET}}}{\delta_{\mathrm{T}}-\delta_{\mathrm{E}}} F_{\mathrm{ET}}$,

$F_{\mathrm{T}}=\frac{\delta_{\mathrm{ET}}-\delta_{\mathrm{E}}}{\delta_{\mathrm{T}}-\delta_{\mathrm{E}}} F_{\mathrm{ET}}$.

The total evaporation flux $\left(F_{\mathrm{E}}\right)$ can be directly calculated using hydrometric methods as described in Sect. 2.2 (eddy covariance, Bowen ratio, lysimeter, etc.).

Isotopic composition in each evaporation component can be obtained from direct measurements (e.g., using a bare soil lysimeter), and calculated using empirical methods. The Craig-Gordon formulation has often been used to calculate the isotopic composition of transpiration $\left(\delta_{\mathrm{T}}\right)$ and soil evaporation or open water evaporation $\left(\delta_{\mathrm{E}}\right.$; Craig and Gordon, 1965). The principle of this conceptual method is that the isotopic composition of the net soil evaporation or transpiration (extended Craig-Gordon model) flux can be derived as a function of environmental parameters (e.g., temperature, humidity). In this model, measurements of isotopic composition in the evaporating front of soil water $\left(\delta_{\mathrm{e}}\right)$, isotopic composition in water vapor $\left(\delta_{\mathrm{v}}\right)$, temperature, and relative humidity are required to calculate $\delta_{\mathrm{E}}$. For this method, the determination of the depth of the evaporating front and isotopic composition of water vapor are crucial. The soil evaporating front, which is defined as the transition zone between the liquid and vapor diffusion, can be determined from the profiles of soil water isotopic composition. This position (usually between 0.1 and $0.5 \mathrm{~m}$ ) (Barnes and Allison, 1983; Kendall and McDonnell, 1998; Clark and Fritz, 1997; Wang and Yakir, 2000, and Sutanto et al., 2012) is clearly marked by the enrichment of heavy isotopes in the soil water above the front due to soil evaporation and depletion of heavy isotopes in the soil water below the front due to diffusion and capillary rise (see Fig. 2). This implies that detailed measurements of the isotopic composition of soil water in the vertical soil profile are needed. The isotopic composition of water vapor can be measured directly; sometimes it is assumed that $\delta_{\mathrm{v}}$ is in equilibrium with precipitation.

The isotopic composition of transpiration can be estimated from measurement of water in leaves, or calculated based on an empirical method (e.g., Craig-Gordon method). In the Craig-Gordon method, the isotopic composition of transpiration is calculated from the modeled values of leaf water enrichment $\left(\delta_{\mathrm{L}}\right)$. Under steady-state conditions, the isotopic composition of leaf water is assumed equal to the isotopic composition of plant source water, being stem water or soil water in the rooting zone. However, this assumption is generally not satisfied for short (hourly to daily) timescales and not valid under rapidly changing environmental conditions (Yepez et al., 2005; Lee et al., 2007; Welp et al., 2008; Xu et al., 2008; Zhang et al., 2010; Wang et al., 2012a). Some studies observed that a modeled transpiration under the steadystate assumption (SSA) is similar to measurements when stomata were fully open. This condition is only met during the afternoon (Yepez et al., 2005; Farquhar and Cernusak, 2005; Lai et al., 2006; Zhang et al., 2010). Some methods exist to estimate the isotopic composition of leaf water in non-steady-state conditions. A non-steady-state model proposed by Dongmann et al. (1974), and the FarquharCernusak model (Farquhar and Cernusak, 2005) can be used to calculate $\delta_{\mathrm{L}}$ (see also Zhang et al., 2010). According to Farquhar and Cernusak (2005), the degree of isotopic enrichment of transpired water under non-steady-state conditions is related to the leaf water content and its isotopic enrichment above source water (isostorage), and it changes over time in the leaf. Wang et al. (2010, 2012a) describe a method to measure $\delta_{\mathrm{T}}$ using a customized leaf chamber in a $100 \% \mathrm{~N}_{2}$ atmosphere. This method requires a measurement of water vapor isotopic composition and water vapor concentration to estimate the $\delta_{\mathrm{L}}$ signal.

A method commonly used to estimate isotopic composition of evaporation $\left(\delta_{\mathrm{ET}}\right)$ is the Keeling plot approach (Keeling, 1958). It expresses a mass balance relationship by plotting the isotopic values of air samples at different heights above the ground $\left(\delta_{\mathrm{V}}\right)$ against the inverse of concentration of the substance of interest, for instance, water vapor mixing ratios (Yepez et al., 2003; Xu et al., 2008; Zhang et al., 2010). This results in a linear relationship where the vertical intercept reflects the isotopic composition of evaporation $\left(\delta_{\mathrm{ET}}\right)$. This method uses three assumptions: (1) there is no loss of water vapor from the system apart from turbulent mixing with the atmosphere, (2) the atmospheric concentration of vapor in the system combines the input from background vapor and an additional component from local evaporation, and (3) the isotopic composition of the two sources does not change during measurements. Again, this method assumes steady state for $\delta_{\mathrm{ET}}$ over the sampling period, which is not always valid in nature.

\subsection{Hydrometric method}

Measurements of direct transpiration are available using hydrometric devices. A widely used quantity to determine continuous transpiration through tree stems and branches is sap flow (Granier, 1985). However, sap flow measurements need to be combined with methods measuring total evaporation to quantify the relative contribution of transpiration to the evaporating flux. Eddy covariance, Bowen ratio techniques, and lysimeters are commonly used in combination with sap flow to calculate the evaporation.

Measurement of transpiration using the sap flow method is based on asymmetric heat transfer by upward- or downwardmoving tissue moisture. There are three well-known sap flow 
methods, which are heat pulse velocity (HPV), heat field deformation (HFD), and thermal dissipation (TD). In the HPV and HFD methods, the thermal dissipation probe (TDP) needles are implanted in the active xylem up- and downstream from a heat source, whereas in the TD method, the TDP is installed downstream from the heat source. The velocity of water through the plant is minimal when the temperature difference between two needles is maximal. On the other hand, the velocity of water increases when the temperature difference decreases.

Evaporation measured by the eddy covariance system is defined as the flux of $\mathrm{H}_{2} \mathrm{O}$ through a horizontal plane above the canopy. Simultaneous high-frequency vertical wind speed and atmospheric water vapor measurements are needed since this method correlates fast fluctuations of vertical wind speed with fast fluctuations in atmospheric water vapor density (Nouri et al., 2013).

Another method to measure evaporation is the Bowen ratio energy balance. This is a micrometeorological method used to estimate latent heat flux, which is calculated by measurements of the temperature and humidity gradients above the canopy (Bowen, 1926). Unlike the eddy covariance and lysimeter methods it is an indirect method; it uses the ratio of the temperature and moisture gradient to partition the available energy (net radiation minus soil heat flux) over latent and sensible heat fluxes.

A lysimeter measures the evaporation loss by weighing an isolated soil sample. Ideally, lysimeters should contain undisturbed soil samples to represent the direct surroundings. Evaporation is calculated from the weight change over time, corrected for precipitation gains and losses (e.g., drainage water and percolate water).

More methods to determine the evaporation exist (Brutsaert et al., 1982; Shuttleworth, 1993). A summary of the advantages and disadvantages of these hydrometric methods can be found in Nouri et al. (2013) (Table 1).

\subsection{Evaporation components in global land-surface models}

In land-surface models, a simple water balance method is commonly applied to calculate surface fluxes. Evaporation as one of the water balance components is calculated as a sum of soil evaporation, transpiration, and canopy interception. Each of these fluxes can be estimated separately using a collection of methods. The most common methods to calculate soil evaporation and transpiration are the ones developed by Priestly and Taylor (Priestly and Taylor, 1972) and by Penman and Monteith (Monteith, 1981). Horton's model adopted for partial canopy cover can be used to calculate interception (Horton, 1919). All these methods require many parameters such as climatological and vegetation parameters, which can be obtained from the satellite data and measurements. An example of this partitioning work can be seen in Choudhury and DiGirolamo (1998).
The development of remote sensing technology has improved the representation of vegetation in these models. In recent land-surface models, LAI (leaf area index) is an important component in formulating soil evaporation, transpiration, and canopy evaporation. Lawrence and Slingo (2004) described in detail the use of LAI in the land-surface model MOSES2 (Met Office Surface Exchange Scheme) to estimate individual evaporation components. In this model, the distribution of soil evaporation and transpiration is controlled by two MOSES2 extinction parameters: the extinction coefficient for photosynthetically active radiation $\left(k_{\mathrm{par}}\right)$ and a shading factor controlling the fraction of the surface that is exposed to the atmosphere above the canopy $\left(k_{\mathrm{sh}}\right)$. Adjusting these two parameters leads to adjusting the transpiration fraction. Increasing $k_{\text {par }}$ means decreasing the fraction of light for photosynthesis and therefore will decrease the transpiration fraction. On the other hand, decreasing $k_{\mathrm{sh}}$ increases the fraction of surface exposed to the atmosphere and therefore will increase the contribution of soil evaporation. The precise values for these two parameters in land-surface models remain a source of uncertainty (Lawrence and Slingo, 2004).

Another attempt to separate the different evaporation terms is applied using the CLM3 model (Community Land Model Version 3; Collins et al., 2006). Lawrence et al. (2007) noted that this model partitions the global evaporation fraction in an unrealistic manner, giving $13 \% E_{T}, 44 \% E_{S}$, and $43 \% E_{I}$. In their study, they tried to improve the fraction of transpiration in the CLM3 model by modifying several parameters and performing a sensitivity analysis. These efforts increase the final transpiration fraction in the CLM3 model from 13 to $44 \%$. However, this value is still somewhat lower than results from the Global Soil Wetness Project 2 (GSWP2; Dirmeyer et al., 2006), which calculates a transpiration fraction of $48 \%$.

\section{Results from past partitioning works}

Many studies partition the evaporation fraction into basically soil evaporation and transpiration. Only few studies take the evaporation from intercepted water into account. Here, we summarize some partitioning studies using the three different methods presented above for comparison (see Fig. 1 and Table 2 for detailed information). It is seen that, in general, hydrometric and isotope-based methods give higher transpiration fraction values than the global land-surface models. On average, the hydrometric method calculates transpiration fractions exceeding $50 \%$, whereas the isotope-based method produces transpiration fractions higher than $70 \%$. Global land-surface models estimate the transpiration fraction to be approximately $50 \%$, except for a recent study by Miralles et al. (2011) (orange bars in Fig. 1). However, these studies have generally been carried out at different locations, for different surface types, different climatic conditions, and different seasons. For global analysis, the global modeling 
Table 1. Summary of hydrometric methods (adopted from Nouri et al., 2013).

\begin{tabular}{|c|c|c|}
\hline Methods & Advantages & Disadvantages \\
\hline Sapflow & $\begin{array}{l}\text { - direct measurement of transpiration } \\
\text { - cheap } \\
\text { - manual or automatic measurement } \\
\text { - individual plant coefficient can be determined } \\
\text { - accurate technique to study plant } \\
\text { ecophysiology and water scheduling }\end{array}$ & $\begin{array}{l}\text { - point-based measurement } \\
\text { - only works for woody species } \\
\text { - some errors may occur from the space between } \\
\text { probes, the variable geometry of stems, } \\
\text { the variation of heat ratio, and uncertainty in } \\
\text { measuring soil and understory evaporation }\end{array}$ \\
\hline Eddy covariance & $\begin{array}{l}\text { - direct method to study mixed vegetation } \\
\text { - suitable for large areas } \\
\text { - feasible to predict evaporation and no need for } \\
\text { specific evaporation equation for different } \\
\text { species }\end{array}$ & $\begin{array}{l}\text { - expensive } \\
\text { - need well-trained operators in electronics } \\
\text { - need a monitoring tower above canopy and } \\
\text { a uniform fetch }\end{array}$ \\
\hline Bowen ratio energy balance & $\begin{array}{l}\text { - simple and cheap } \\
\text { - can measure evaporation even from } \\
\text { non-watered plantation surface } \\
\text { - proved to be a robust method in many forestry } \\
\text { areas }\end{array}$ & $\begin{array}{l}\text { - need uniform fetch for accurate measurement of } \\
\text { net radiation and soil heat flux } \\
\text { - need an adequate elevation above the canopy to } \\
\text { collect the required meteorological data } \\
\text { - sensitive to the bias of instrument gradient } \\
\text { and energy balance }\end{array}$ \\
\hline Lysimeter & $\begin{array}{l}\text { - easy for inspection } \\
\text { - manual or automatic measurement } \\
\text { - high accuracy for undisturbed soil }\end{array}$ & $\begin{array}{l}\text { - point-based measurement } \\
\text { - very sensitive to different vegetation conditions } \\
\text { inside and outside lysimeter } \\
\text { - not practical for mixed vegetation types at large } \\
\text { spacing } \\
\text { - must consider plant root development } \\
\text { - may have edge-flow effect } \\
\text { - difficult to install and maintenance }\end{array}$ \\
\hline
\end{tabular}

methods give global annually averaged results that are lower than the contribution of the transpiration fraction derived from the isotope-based method from Jasechko et al. (2013) (80-90\%).

The portion of transpiration varies as a function of many factors such as radiation, air temperature, air humidity, wind, soil water content, crop characteristic, etc. For cultivated land, the crop development stage, environment, irrigation practice, and crop management all also strongly influence the transpiration rate. Under optimal conditions the transpiration flux may reach more than $90 \%$ of the evaporation, but it can drop to values lower than soil evaporation when plants are in a dormant or under less favorable conditions (Robertson and Gazis, 2006; Cavanaugh et al., 2011).

This temporal variation has been identified in many studies (including isotope-based partitioning studies), which show that transpiration during the growing season or summer is a dominant water flux compared to other fluxes, in general more than $70 \%$ of the total evaporation (Lee et al., 2010; Wang et al., 2010, 2012a, b; Wenninger et al., 2010; Zhang et al., 2011; Sutanto et al., 2012), with some studies (Robertson and Gazis, 2006; Xu et al., 2008) reporting transpiration fractions exceeding $90 \%$ of the total evaporation flux. For crops (Allen et al., 1998), the transpiration flux may be more than $90 \%$ of the total evaporation at full crop cover. However, during autumn (September-November), the transpiration fraction may drop to below $30 \%$, the remaining moisture flux being soil evaporation (Robertson and Gazis, 2006).

A seasonal cycle of hydrological recycling rates modulated by surface evaporation is evident over many of the midlatitude regions (Dirmeyer and Brubaker, 2007). At higher temperatures, the fractionation processes associated with evaporation and condensation lead to higher isotopic enrichment of precipitation during summer than winter, known as the "temperature effect". In Europe, for example, intensified recycling in spring/summer with a comparably enriched isotope value, and a reduced contribution of local evaporation to the atmospheric water vapor during autumn/winter is prominently visible in the water isotopologues. In summer, a large evaporation fraction leads to a small spatial isotope enrichment gradient from the Atlantic coast to the interior of the continent. A steeper spatial gradient of depleted heavy isotopologue in winter appears from a strongly reduced contribution of continental water sources (evaporation fluxes) to the incoming water vapor masses (Rozanski et al., 1982; Hoffmann et al., 1998).

Different plant types exhibit a different transpiration fraction under similar climatic condition. Examples have been reported in some isotope studies in the US and China. In the US, studies by Yepez et al. (2003) and Ferretti et al. (2003) in Arizona and Colorado show that the transpiration fractions 
Table 2. Transpiration fraction from several past partitioning studies. $T, E$, and $I$ stand for transpiration, soil evaporation and interception, respectively.

\begin{tabular}{|c|c|c|c|c|c|c|c|}
\hline Authors & $\begin{array}{l}\text { Transpiration } \\
\text { fractions }\end{array}$ & Locations & Climatological & $\begin{array}{l}\text { General } \\
\text { methods }\end{array}$ & Methods & $\begin{array}{l}\text { Measured } \\
\text { fluxes }\end{array}$ & Plant types \\
\hline $\begin{array}{l}\text { Sutanto et al. } \\
\text { (2012) }\end{array}$ & $77.7 \%$ & Laboratory & $\begin{array}{l}\text { Represents } \\
\text { the Nether- } \\
\text { lands' sum- } \\
\text { mer }\end{array}$ & $\begin{array}{l}\text { Isotope-based } \\
\text { method }\end{array}$ & $\begin{array}{l}\text { Isotope mass } \\
\text { balance }\end{array}$ & $T, E, I$ & Grass \\
\hline $\begin{array}{l}\text { Williams et } \\
\text { al. (2004) }\end{array}$ & $\begin{array}{l}69-86 \% \text { dur- } \\
\text { ing midday }\end{array}$ & Morocco & $\begin{array}{l}\text { Oct- } \\
\text { Nov } 2002\end{array}$ & $\begin{array}{l}\text { Isotope-based } \\
\text { method }\end{array}$ & $\begin{array}{l}\text { Eddy } \text { covari- } \\
\text { ance, sap } \\
\text { flow, Keeling } \\
\text { plot }\end{array}$ & $T, E$ & $\begin{array}{l}\text { Olive or- } \\
\text { chard }\end{array}$ \\
\hline $\begin{array}{l}\mathrm{Xu} \text { et al. } \\
(2008)\end{array}$ & $65-96 \%$ & China & Jun 2006 & $\begin{array}{l}\text { Isotope-based } \\
\text { method }\end{array}$ & Keeling plot & $T, E$ & Oaks \\
\hline $\begin{array}{l}\text { Ferretti et al. } \\
\text { (2003) }\end{array}$ & $\begin{array}{l}76-87 \% \\
\text { growing } \\
\text { season }\end{array}$ & Colorado & $\begin{array}{l}\text { May 2000- } \\
\text { Oct } 2001\end{array}$ & $\begin{array}{l}\text { Isotope-based } \\
\text { method }\end{array}$ & $\begin{array}{l}\text { Isotope mass } \\
\text { balance }\end{array}$ & $T, E$ & Shortgrass \\
\hline $\begin{array}{l}\text { Wang et al. } \\
\text { (2010) }\end{array}$ & $61-83 \%$ & Laboratory & Controlled & $\begin{array}{l}\text { Isotope-based } \\
\text { method }\end{array}$ & $\begin{array}{l}\text { Keeling plot, } \\
\text { lysimeter, sap } \\
\text { flow }\end{array}$ & $T, E$ & $\begin{array}{l}\text { Woody } \\
\text { plant }\end{array}$ \\
\hline $\begin{array}{l}\text { Robertson } \\
\text { and Gazis } \\
(2006)\end{array}$ & $\begin{array}{l}\text { Autumn 28- } \\
77 \% \text {, spring } \\
57-98 \%\end{array}$ & Washington & 2000-2001 & $\begin{array}{l}\text { Isotope-based } \\
\text { method }\end{array}$ & $\begin{array}{l}\text { Isotope mass } \\
\text { balance }\end{array}$ & $T, E$ & $\begin{array}{l}\text { Shrub- } \\
\text { steppe and } \\
\text { pine }\end{array}$ \\
\hline $\begin{array}{l}\text { Wenninger et } \\
\text { al. }(2010)\end{array}$ & $70 \%$ & Laboratory & Controlled & $\begin{array}{l}\text { Isotope-based } \\
\text { method }\end{array}$ & $\begin{array}{l}\text { Isotope mass } \\
\text { balance }\end{array}$ & $T, E$ & Teff grass \\
\hline $\begin{array}{l}\text { Yepez et al. } \\
(2003)\end{array}$ & $85 \%$ & Arizona, US & Jul-Sep 2001 & $\begin{array}{l}\text { Isotope-based } \\
\text { method }\end{array}$ & Keeling plot & $T, E$ & $\begin{array}{l}\text { Savanna } \\
\text { woodland }\end{array}$ \\
\hline $\begin{array}{l}\text { Zhang et al. } \\
\text { (2011) }\end{array}$ & $60-80 \%$ & China & $\begin{array}{l}\text { Mar- } \\
\text { Jun } 2009\end{array}$ & $\begin{array}{l}\text { Isotope-based } \\
\text { method }\end{array}$ & $\begin{array}{l}\text { Eddy covari- } \\
\text { ance, Keeling } \\
\text { plot }\end{array}$ & $T, E$ & Wheat, corn \\
\hline $\begin{array}{l}\text { Jasechko et } \\
\text { al. (2013) }\end{array}$ & $80-90 \%$ & Global & - & $\begin{array}{l}\text { Isotope-based } \\
\text { method }\end{array}$ & $\begin{array}{l}\text { Lake catch- } \\
\text { ments }\end{array}$ & $T, E$ & - \\
\hline $\begin{array}{l}\text { Lee et al. } \\
(2010)\end{array}$ & $48 \%$ & China & - & $\begin{array}{l}\text { Isotope-based } \\
\text { method }\end{array}$ & $\begin{array}{l}\text { Isotope mass } \\
\text { balance }\end{array}$ & $T, E, I$ & - \\
\hline $\begin{array}{l}\text { Yepez et al. } \\
(2005)\end{array}$ & $\begin{array}{l}40-74 \% \\
\text { day, } 28-42 \% \\
\text { night }\end{array}$ & Arizona, US & Jun 2003 & $\begin{array}{l}\text { Isotope-based } \\
\text { method }\end{array}$ & Keeling plot & $T, E$ & Grass \\
\hline $\begin{array}{l}\text { Lai et al. } \\
(2006)\end{array}$ & $85 \%$ & $\begin{array}{l}\text { Southern } \\
\text { Washington, } \\
\text { US }\end{array}$ & Summer 2002 & $\begin{array}{l}\text { Isotope-based } \\
\text { method }\end{array}$ & $\begin{array}{l}\text { Isotope mass } \\
\text { balance, eddy } \\
\text { covariance, } \\
\text { sap flow }\end{array}$ & $T, E$ & Coniferous \\
\hline $\begin{array}{l}\text { Herbst et al. } \\
\text { (1996) }\end{array}$ & $77-97 \%$ & $\begin{array}{l}\text { Northern } \\
\text { Germany }\end{array}$ & $\begin{array}{l}\text { May- } \\
\text { Aug } 1995\end{array}$ & $\begin{array}{l}\text { Hydrometric } \\
\text { method }\end{array}$ & $\begin{array}{l}\text { Porometer, } \\
\text { lysimeter, } \\
\text { Bowen ratio }\end{array}$ & $T, E$ & Maize \\
\hline $\begin{array}{l}\text { Roupsard et } \\
\text { al. (2006) }\end{array}$ & $68-89 \%$ & $\begin{array}{l}\text { Vanuatu, } \\
\text { South Pacific }\end{array}$ & $\begin{array}{l}\text { Oct 2001- } \\
\text { Sep } 2004\end{array}$ & $\begin{array}{l}\text { Hydrometric } \\
\text { method }\end{array}$ & $\begin{array}{lr}\text { Eddy } & \text { covari- } \\
\text { ance, } & \text { sap } \\
\text { flow, } & \text { Bowen } \\
\text { ratio } & \end{array}$ & $T, E$ & Coconut \\
\hline $\begin{array}{l}\text { Mitchell et al. } \\
\text { (2009) }\end{array}$ & $\begin{array}{ll}53 \% & \text { sum- } \\
\text { mer, } & 22 \% \\
\text { winter } & \end{array}$ & Australia & $\begin{array}{l}\text { Mar 2006- } \\
\text { Feb } 2007\end{array}$ & $\begin{array}{l}\text { Hydrometric } \\
\text { method }\end{array}$ & $\begin{array}{l}\text { sap flow, hy- } \\
\text { drometric de- } \\
\text { vices }\end{array}$ & $T, E, I$ & Eucalypt \\
\hline $\begin{array}{l}\text { Kelliher et al. } \\
\text { (1992) }\end{array}$ & $80 \%$ & New Zealand & Mar 1991 & $\begin{array}{l}\text { Hydrometric } \\
\text { method }\end{array}$ & $\begin{array}{l}\text { Sap flow, } \\
\text { eddy covari- } \\
\text { ance }\end{array}$ & $T, E$ & Beech \\
\hline $\begin{array}{l}\text { Cavanaugh et } \\
\text { al. (2011) }\end{array}$ & $42-47 \%$ & Arizona, US & Summer 2008 & $\begin{array}{l}\text { Hydrometric } \\
\text { method }\end{array}$ & $\begin{array}{l}\text { Sap flow, } \\
\text { eddy covari- } \\
\text { ance }\end{array}$ & $T, E$ & Shrubland \\
\hline $\begin{array}{l}\text { Lawrence et } \\
\text { al. (2007) }\end{array}$ & $41 \%$ & Global & - & Model & CLM3 & $T, E, I$ & - \\
\hline $\begin{array}{l}\text { Choudhury } \\
\text { and Di- } \\
\text { Girolamo } \\
(1998)\end{array}$ & $\begin{array}{l}52 \% \text { global, } \\
76 \% \text { forested } \\
\text { area }\end{array}$ & Global & - & Model & $\begin{array}{l}\text { Biophysical- } \\
\text { based model }\end{array}$ & $T, E, I$ & - \\
\hline $\begin{array}{l}\text { Dirmeyer et } \\
\text { al. (2006) }\end{array}$ & $48 \%$ & Global & - & Model & GSWP2 & $T, E, I$ & - \\
\hline $\begin{array}{l}\text { Miralles et al. } \\
\text { (2011) }\end{array}$ & $80 \%$ & Global & - & Model & GLEAM & $T, E, I$ & - \\
\hline $\begin{array}{l}\text { Schlesinger } \\
\text { and Jasechko } \\
(2014)\end{array}$ & $61 \%$ & Global & - & Combination & - & $T, E$ & - \\
\hline
\end{tabular}




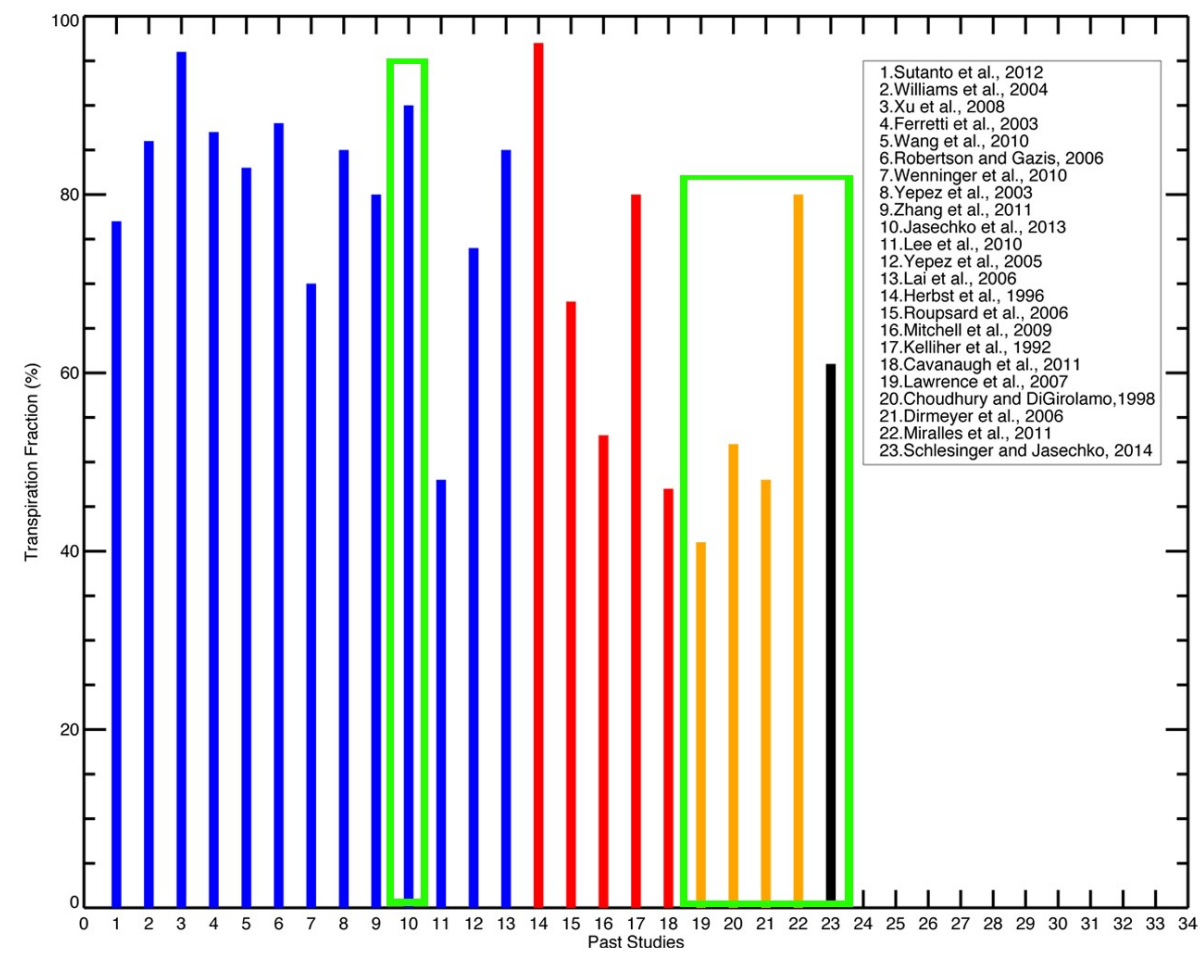

Figure 1. Transpiration fraction from several past partitioning studies. The plot shows maximum values of transpiration fraction from those studies. Blue is for isotope-based methods, red is for hydrometric methods, orange is for global land-surface model results, and black is a combination hydrometric and model result. The studies inside the green boxes present global average values.

from savanna woodland and grass are 85 and $76-87 \%$, respectively, in summer. In Washington, partitioning results in early summer from Robertson and Gazis (2006) give a transpiration fraction of $57-88 \%$ for a steppe-forest region. In China during summer, the transpiration fractions of oaks and wheat are 96 and $80 \%$, respectively (Xu et al., 2008; Zhang et al., 2011). This indicates that, during summer, different plant species may have different transpiration fractions under the same climatic conditions. Savanna woodland has a higher transpiration fraction than grass in the US and an oak stand has a higher transpiration fraction than wheat in China. In addition, Kool et al. (2014) compile some partitioning studies and show that the transpiration fraction of a cotton field was $70-80 \%$ and the transpiration fractions of corn, wheat, and soybean fields were lower, approximately $60-70 \%$.

Much lower transpiration fractions have been reported in Arizona, US, with hydrometric methods. A study by Cavanaugh et al. (2011) during summer in a shrubland area showed a transpiration fraction of $42-47 \%$. This is very low compared to an isotope-based study in the same region, although different plant types are examined $(\sim 85 \%$ for savanna woodland). However, this does not necessarily imply the hydrometric method generally yields much lower results compared to the isotope-based method. In Europe during summer, results from an isotope-based method to partition the transpiration fraction from grass and a hydrometric method to partition the transpiration fraction from maize are very comparable, yielding $78 \%$ transpiration for grass (Sutanto et al., 2012) and 77-97\% for maize (Herbst et al., 1996). Sutanto et al. (2012) also show that the evaporation rates analyzed from isotope-based and hydrometric methods are similar (3.4 and $3.5 \mathrm{~mm} \mathrm{~d}^{-1}$, respectively). In addition, Williams et al. (2004) present a comparison of isotope-based and hydrometric methods in an olive tree site. Their study shows agreement between the two approaches for the midday period (10:30 to 12:30) though slightly different values are found for the late-afternoon period (14:30 to 16:30), with differences of $4 \%$ for transpiration. In general, the difference between the isotope-based method and the hydrometric method is small if the same plants and climatic conditions are considered. The possible reasons why the isotope-based method slightly overestimates the transpiration fraction due to its limitations and assumptions are discussed in Sect. 4.

For global-scale partitioning analysis, only few studies quantify the transpiration fraction from the total evaporation. The study by Jasechko et al. (2013) is the first one that reports a global transpiration fraction based on an isotope approach. This study concluded that the transpiration fraction is 80 to $90 \%$. Using another set of input data, Coenders-Gerrits et al. (2014) estimate a transpiration fraction of 35-80\% globally using the same method as Jasechko et al. (2013). Moreover, a recent compilation study by Schlesinger and Jasechko (2014) 
results in a transpiration fraction of $61 \%( \pm 15 \% \mathrm{SD})$. These two recent studies indicate that the estimate for the transpiration fraction of $80-90 \%$ is likely to be biased high. In addition, these studies may not necessarily be representative for all continental areas since the calculation is derived from the isotopic composition of large lake water bodies and averaged from some studies in some places only.

Existing model and field estimates of the transpiration fraction do not support values higher than $80 \%$ (GSWP2, CLM3). A relatively high transpiration fraction of $80 \%$ is simulated by GLEAM (Global Land-surface Evaporation: the Amsterdam Methodology; Miralles et al., 2011); however, in general, global land-surface models produce a lower transpiration fraction than the isotope-based method. Global averaged results may underestimate the transpiration fraction compared to field studies because they represent the global annual average and not seasonal averages. Many isotopebased and hydrometric studies have been carried out during spring and summer seasons, which have higher transpiration fractions compared to the autumn and winter seasons. Also, the transpiration fraction is not the same everywhere, as it depends on surface types and climatic conditions. Other field measurement programs estimate the fraction of transpiration to be around $52 \%$ globally, $65-76 \%$ for forest, and $60 \%$ for grasses (Choudhury and DiGirolamo, 1998; Blyth and Harding, 2011).

\section{Possible discrepancies}

What can explain these systematic discrepancies between the isotope and non-isotope methods? We have shown above that each technique has its own limitations and these may lead to biases in the results. The main source of inaccuracy in lysimeter methods is the edge-flow of water that can occur in the contact area between bucket and soil. This produces a significant error in the calculation of water losses from the lysimeter. Sap flow measurements suffer from leaking through the contact between tree and probes, probe misalignment, geometry of stems, the spatial variation of thermal conductivity, calibration difficulties, and the inaccuracy of the methods. According to Steppe et al. (2010), the three sap flow methods (HPV, HFD, and TD) underestimate the actual sap flux density by 35,46 , and $60 \%$, respectively. Some studies (Allen et al., 2011; Burba and Anderson, 2007; Billesbach, 2011; Nagler et al., 2005) review the errors in eddy covariance techniques, which include the assumptions used in calculations, instrument problems, frequency response, sensor time delays, noise, instrument calibration, etc. For the Bowen ratio method, a main source of uncertainty is the limited accuracy of the instrument to detect (sometimes very small) gradients (Todd et al., 2000; Nouri et al., 2013; Herbst et al., 1996).

For the isotope approach, the assumptions underlying the Keeling plot method used to calculate isotopic composition of evaporation as described in Sect. 2.1 are rarely met perfectly in nature. The isotopic composition of water vapor is not constant during the period of interest, which can be caused by, for example, loss of water due to condensation, influence of air mass advection, entrainment at the boundary layer, etc. The isotopic composition of leaf water also changes over time: it is generally higher during the day than during the night (Farquhar and Cernusak, 2005; Yepez et al., 2005; Lai et al., 2006). The SSA may produce a reasonable $\delta_{\mathrm{L}}$ approximation in the afternoon, when stomata are relatively open. On the other hand, plants do not transpire under SSA conditions during the night. The SSA may lead to an overestimation of the isotopic composition of leaf water compared to the measurements. Moreover, SSA is not satisfied in many field conditions when canopy climatic conditions are highly variable (Dongmann et al., 1974; Flanagan et al., 1991; Farquhar and Cernusak, 2005; Yepez et al., 2005). A failure to correctly calculate the isotopic enrichment of leaf water precisely will produce a bias in the transpiration fraction analysis. Therefore the assumption of steady-state non-fractionating transpiration flux and a fractionation of all remaining surface fluxes should be critically reassessed.

According to this assumption, the isotope signature of the source water will not be altered by transpiration or by canopy and litter interception from low vegetation such as grass. However, Gehrels et al. (1998) showed that the isotopic composition of soil water in forested areas is heavier than in non-forested areas, where the isotope signature of soil water is similar to the respective precipitation. Frequency and amount of rain will effectively modify the fractionation of interception and soil water. Over vegetated areas, precipitation is partly intercepted by the canopy, where it is exposed to open evaporation and accompanying fractionation. If followed by a new shower before the interception water is evaporated entirely, the enriched interception water is washed off and may cause an enrichment of soil water similar to a situation without the existence of a canopy with large leaves. Also, the evaporation from intercepted water on canopy or litter, which is not taken into account in many isotope-based studies, may overestimate the transpiration contribution. A study by Tsiko et al. (2012) in a savanna ecosystem shows that evaporation from intercepted water yields a $50 \%$ interception fraction of the total evaporation.

The difference in the effective fractionation of the water isotopologues between transpiration on the one hand and evaporation from bare soils and lakes on the other is key for the isotopic method to deliver quantitative constraints. Several studies (Yepez et al., 2005; Lai et al., 2006; Lee et al., 2007; Cuntz et al., 2007; Ogée et al., 2007) have shown that both fluxes (from non-fractionating vegetation and fractionating soils and open waters) show a strong seasonal and diurnal variability. For instance, in a dry season, vegetation with deep roots has access to water from deeper soil layers or groundwater (Moreira et al., 1997; Wang and Yakir, 2000; Lee et al., 2007). The isotopic composition of 

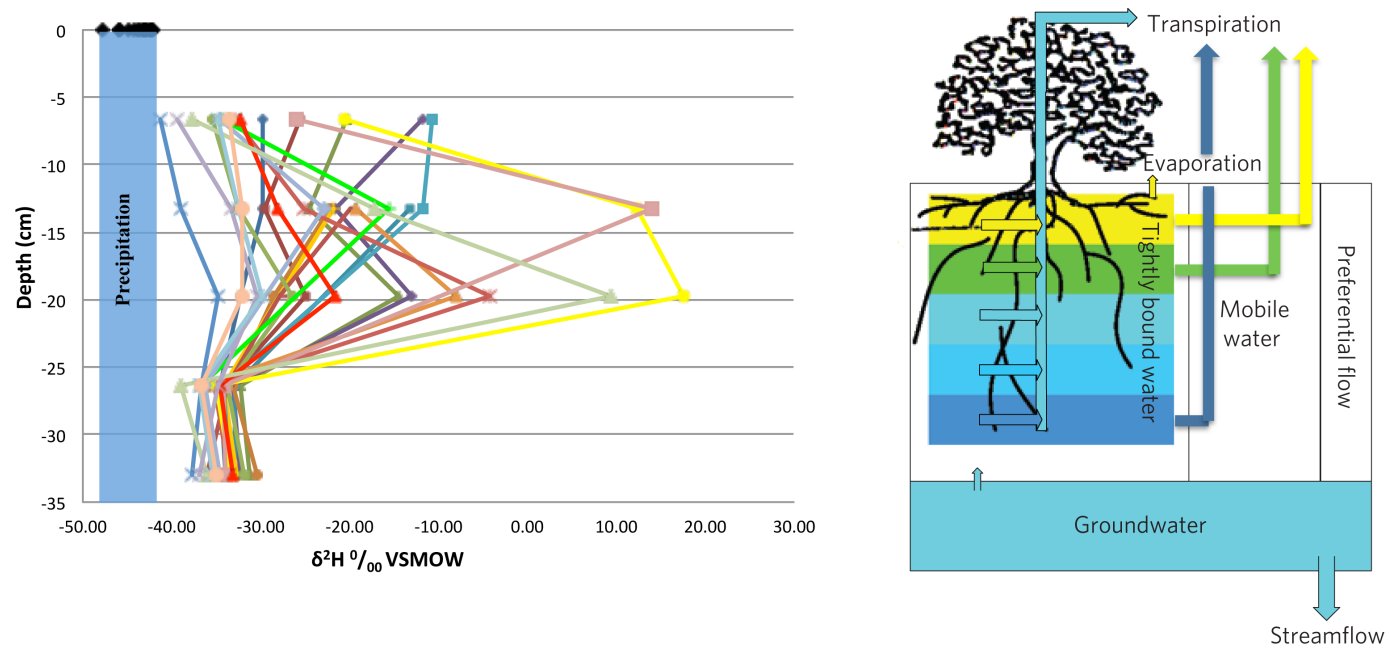

Figure 2. Left panel: soil water isotope profiles and evaporating front in a lysimeter experiment from a collection of soil samples from Sutanto et al. (2012); different colors represent different sampling periods. Right panel: a transpiration illustration from Brooks et al. (2010); different colors indicate different soil water isotopic values, with enriched isotopic values close to the surface and more depleted isotopic values in the bottom layers.
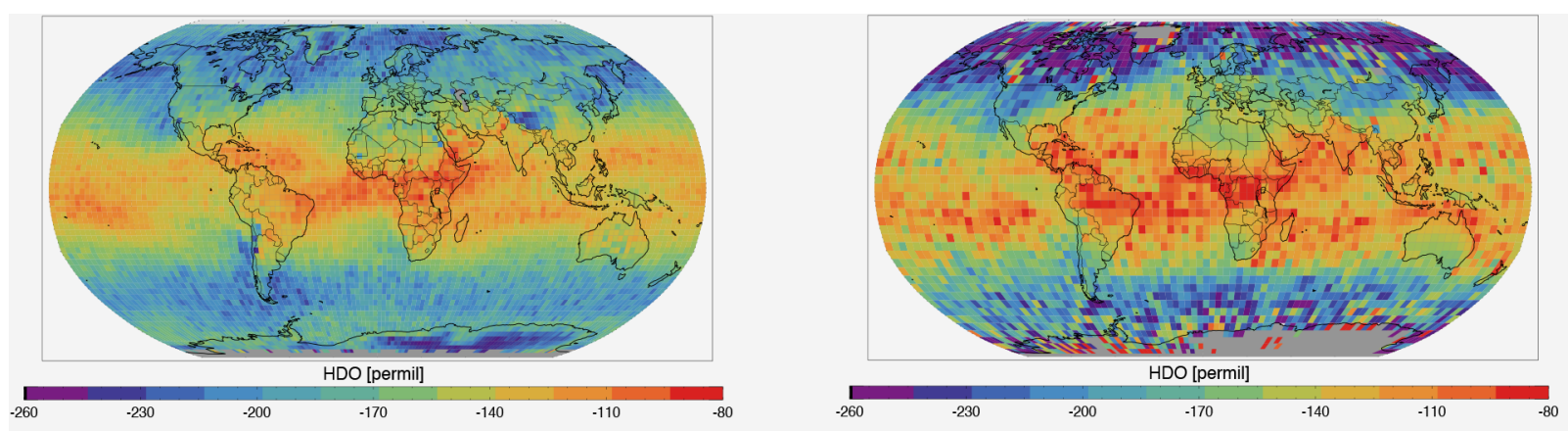

Figure 3. Water vapor isotopic composition $(\delta \mathrm{D})$ measured from TES (version 5, year 2006, weighted averaged from 900 to $425 \mathrm{hPa}$, left panel) and SCIAMACHY (average over 2003 to 2005, total column, right panel) satellites. Red colors indicate an enrichment in heavy isotopes and blue and purple colors indicate a depletion in heavy isotopes.

groundwater depends on the isotopic input during the main recharge season, i.e., it is more enriched during summer than winter. Due to the fact that groundwater recharge is usually stronger in winter than in summer, the deep water will generally be more depleted than the upper layer/nearsurface water. Thus, the assumption that is often used in the isotope-based method, stating that deeper water reflects the isotope composition of precipitation, is not necessarily true. In addition, near-surface water (accessible for shortrooted plants) has often undergone isotopic enrichment by evaporation from bare soils. Hence extensive transpiration from vegetation with deep roots will generally result in an atmospheric water vapor signature that is more depleted of heavy isotopes than transpiration from superficial sources (see Fig. 2), and may lead to an overestimation of the transpiration fraction when this is not taken into account. In isotope-based methods, the isotopic value of transpiration usually only uses isotopic composition of shallow soil water as source water.

Such effects might also contribute to the spatial patterns of isotopes in atmospheric water vapor that are becoming available via satellite-based remote sensing techniques. Water vapor over the Amazon Basin, for example, shows less deuterium enrichment than over tropical Africa in two independent data sets: TES (Worden et al., 2012) and SCIAMACHY (Frankenberg et al., 2009; Fig. 3). This evidence may relate to the contribution of shallow and deep soil water to the transpiration flux: rain forest in the Amazon has access to deeper groundwater reservoirs (Miguez-Macho and Fan, 2012) than most vegetation types in Africa.

Another factor that may contribute to a bias in the calculation of the transpiration fraction using the isotopic composition of open water (e.g., lakes) is the assumed similarity of the isotopic enrichment processes for soil evaporation 
and open water. Haverd et al. (2011) found that, after the first phase of soil drying, the value of the isotopic enrichment of evaporated soil water rapidly reaches a steady-state value, which is approximately equal to that of the transpired water vapor. Thus the top soil layer may act as an isotopically enriched conduct for water from deeper layers without strong overall fractionation between the soil water and evaporated water, similar to the enrichments in leaves during transpiration. This does not apply to the isotopic enrichment of lakes. Partitioning of evaporation using the isotope-based method on the global scale is highly sensitive to the input data and its isotopic composition. Coenders-Gerrits et al. (2014) show that the transpiration fraction calculated using the same method as Jasechko et al. (2013) reduces to 50$80 \%$ if the input data are different, and to $35-80 \%$ if the isotopic composition of transpiration is different.

The discrepancies between transpiration fractions calculated from different models can also be caused by the use of different averaging techniques. Some models include the desert regions (e.g., Sahara and Australian deserts), whereas in other approaches, deserts are ignored. The global transpiration fraction will be lower if the desert regions are included in the calculation. Based on observations, Haverd et al. (2013) estimate that $50 \%$ of the Australian rainfall is lost as bare soil evaporation, which means that less than $50 \%$ of the rainfall is used for transpiration. Moreover, global landsurface-model-based estimates can be strongly biased due to systematic errors and poor representation of relevant processes. The representation of tiling bare ground versus vegetated fractions in models deviates strongly from the true organization of vegetated or bare fractions of natural surfaces. Litter or moss layers are often missing, and the coarse vertical discretization of the soil does not allow for steep moisture gradients near the surface. The relatively low transpiration fraction in current state-of-the-art land-surface models (Dirmeyer et al., 2006) calls for a reassessment of the skill of the underlying model parameterizations. A proper physical interpretation of (tuned) model parameters is still a difficult task (Lawrence and Slingo, 2004).

\section{Conclusions}

Different approaches exist to infer the transpiration fraction of the continental evaporation flux. In general, estimates based on water isotope balance calculations tend to allocate a fairly large contribution of transpiration to the total moisture flux (generally exceeding $70 \%$ of the evaporation fluxes). These results are at or above the upper estimates of the transpiration fraction using other isotope-independent techniques (models, in situ physical flux data). The comparability is limited due to incomplete temporal and spatial coverage of most isotope-based analyses. However, a few studies that compare estimates of evaporation at the same location and conditions using the isotope-based and hydrometric methods show that the results are in good agreement. The relatively low transpiration fraction in land-surface models shows that a reassessment of model parameterizations must be carried out.

The lack of global evaporation partitioning estimates using the isotope-based method and validation of global isotopeindependent techniques using isotope-based results remain a challenge. Continued measurements of global isotopic composition of soil water and water vapor around leaves are needed to put the isotope-based results into context. Isotopeenabled land-surface and global climate modeling studies such as iPILPS (isotopes in the Project for Intercomparison of Land-surface Parameterization Schemes; HendersonSellers et al., 2006) and SWING (Stable Water Isotope Intercomparison Group; Noone, 2007) allow for the evaluation of the parameterization of land-surface models by comparing the computed water isotopologue signals in the atmosphere with the available remote sensing and flux-based data sets. A validation of modeled water isotopologue signals in the atmosphere is needed. We suggest that future studies should perform this evaluation in order to provide a better understanding of the hydrological cycle in vegetated regions.

Acknowledgements. We thank Andy Pitman, Vanessa Haverd, and Matthias Cuntz for helpful comments. The project was funded by the Netherlands Organisation for Scientific Research (NWO) (grant ALW-GO-AO/10-11).

Edited by: M. Weiler

\section{References}

Allen, R. G., Pereira, L. S., Raes, D., and Smith, M.: Crop evapotranspiration-Guidelines for computing crop water requirements-FAO Irrigation and drainage paper 56, FAO - Food and Agriculture Organization of the United Nations, Rome, 1998.

Allen, R. G., Pereira, L. S., Howell, T. A., and Jensen, M. E.: Evapotranspiration information reporting: I. Factors governing measurement accuracy, Agr. Water Manage., 98, 899-920, 2011.

Barnes, C. J. and Allison, G. B.: The distribution of deuterium and ${ }^{18} \mathrm{O}$ in dry soils, 1. Theory, J. Hydrol., 60, 141-156, 1983.

Billesbach, D. P.: Estimating uncertainty in individual eddy covariance flux measurements: a comparison of methods and a proposed new method, Agr. Forest Meteorol., 151, 394-405, 2011.

Blyth, E. M. and Harding, R. J.: Methods to separate observed global evapotranspiration into the interception, transpiration and soil surface evaporation components, Hydrol. Process., 25, 4063-4068, doi:10.1002/hyp.8409, 2011.

Bowen, I. S.: The ratio of heat looses by conduction and by evaporation from any water surface, Phys. Rev., 27, 779-787, 1926.

Brooks, J. R., Barnard, H. R., Coulombe, R., and McDonnell, J. J.: Ecohydrologic separation of water between trees and streams in a mediterranean climate, Nat. Geosci., 3, 100-104, 2010.

Brutsaert, W.: Evaporation into the atmosphere: theory, history, and applications, Reidel, Dordrecht, 1982. 
Burba, G. G. and Anderson, D. J.: Introduction to The Eddy Covariance Method: General 20 Guidelines and Conventional Workflow, LI-COR Biosciences, Lincoln, NE, p. 141, 2007.

Calder, I. R.: Deuterium tracing for the estimation of transpiration from trees Part 2. Estimation of transpiration rates and transpiration parameters using a time-averaged deuterium tracing method, J. Hydrol., 130, 27-35, 1992.

Calder, I. R., Narayanswamy, M. N., Srinivasalu, N .V., Darling, W. G., and Lardner, A. J.: Investigation into the use of deuterium as a tracer for measuring transpiration from eucalypts, J. Hydrol., 84, 345-351, 1986.

Calder, I. R., Kariyappa, G. S., Srinivasalu, N. V., and Murty, K. V. S.: Deuterium tracing for the estimation of transpiration from trees Part 1. Field calibration, J. Hydrol., 130, 17-25, 1992.

Cavanaugh, M. L., Kurc, S. A., and Scott, R. L.: Evapotranspiration partitioning in semiarid shrubland ecosystem: a two-site evaluation of soil moisture control on transpiration, Ecohydrology, 4, 671-681, doi:10.1002/eco.157, 2011.

Choudhury, B. and DiGirolamo, N.: A biophysical process-based estimate of global land surface evaporation using satellite and ancillary data-I. Model description and comparison with observations, J. Hydrol., 205, 164-185, 1998.

Clark, I. and Fritz, P.: Environmental isotopes in hydrogeology, CRC Press, Boca Raton, Florida, 1997.

Coenders-Gerrits, A. M. J., van der Ent, R. J., Bogaard, T. A., WangErlandsson, L., Hrachowitz, M., and Savenije, H. H. G.: Uncertainties in transpiration estimates, Brief Communications Arising, Nature, 506, E1-E2, doi:10.1038/nature12925, 2014.

Collins, W. D., Rasch, P. J., Boville, B. A., Hack, J. J., McCaa, J. R., Williamson, D. L., and Briegleb, B. P.: The formulation and atmospheric simulation of the Community Atmosphere Model Version 3 (CAM3), J. Climate, 19, 2144-2161, 2006.

Craig, H. and Gordon, L. I.: Deuterium and oxygen-18 variations in the ocean and the marine atmosphere, in: Proceedings of the conference on stable isotopes in oceanographic studies and paleotemperatures, edited by: Tongiorgi E., Laboratory of Geology and Nuclear Science, Pisa, 9-130, 1965.

Cuntz, M., Ogée, J., Farquhar, G. D., Peylin, P., and Cernusak, L. A.: Modelling advection and diffusion of water isotopologues in leaves, Plant Cell Environ., 30, 829-909, 2007.

Dirmeyer, P. A. and Brubaker, K. L.: Characterization of the global hydrologic cycle from a back-trajectory analysis of atmospheric water vapor, J. Hydrometeorol., 8, 20-37, doi:10.1175/JHM557.1, 2007.

Dirmeyer, P. A., Gao, X., Zha, M., Guo, Z., Oki, T., and Hanasaki, N.: GSWP-2: Multimodel analysis and implications for our perception of the land surface, B. Am. Meteorol. Soc., 87, 13811397, 2006.

Dongmann, G., Nurnberg, H. W., Forstel, H., and Wagener, K.: On the enrichment of $\mathrm{H}_{2}^{18} \mathrm{O}$ in leaves of transpiring plants, Radiat. Environ. Bioph., 11, 41-52, 1974.

Ehleringer, J. R. and Dawson, T. E.: Water uptake by plants: perspectives from stable isotope composition, Plant Cell Environ., 15, 1073-1082, 1992.

Farquhar, G. D. and Cernusak, L. A.: On the isotopic composition of leaf water in the non-steady state, Funct. Plant Biol., 32, 293303, 2005.
Ferretti, D. F., Pendall, E., Morgan, J. A., Nelson, J. A., LeCain, D., and Mosier, A. R.: Partitioning evapotranspiration fluxes from a Colorado grassland using stable isotopes: Seasonal variations and ecosystem implications of elevated atmospheric $\mathrm{CO}_{2}$, Plant Soil, 254, 291-303, 2003.

Flanagan, L. B., Comstock, J. P., and Ehlinger, J. R.: Comparison od modeled and observed environmental influences of the stable oxygen and hydrogen isotope composition of leaf water in Phaseolus vulgaris L, Plant Physiol., 96, 588-596, 1991.

Frankenberg, C., Yoshimura, K., Warneke, T., Aben, I., Butz, A., Deutscher, N., Griffith, D., Hase, F., Notholt, J., Schneider, M., Schrijver, H., and Röckmann, T.: Dynamic processes governing the isotopic composition of water vapor as observed from space and ground, Science, 325, 1374-1377, doi:10.1126/science.1173791, 2009.

Gehrels, J. C., Peeters, J. E. M., Vries, J. J. D., and Dekkers, M.: The mechanism of soil water movement as inferred from ${ }^{18} \mathrm{O}$ stable isotope studies, Hydrolog. Sci. J., 43, 579-594, 1998.

Granier, A.: Une nouvelle method pour la mesure du flux de sève brute dans le tronc des arbres, Ann. Sci. Forest, 42, 193-200, 1985.

Haverd, V., Cuntz, M., Griffith, D., Keitel, C., Tadros, C., and Twining, J.: Measured deuterium in water vapour concentration does not improve the constraint on the partitioning of evapotranspiration in a tall forest canopy, as estimated using a soil vegetation atmosphere transfer model, Agr. Forest Meteorol., 151, 645-654, 2011.

Haverd, V., Raupach, M. R., Briggs, P. R., Canadell, J. G., Isaac, P., Pickett-Heaps, C., Roxburgh, S. H., van Gorsel, E., Viscarra Rossel, R. A., and Wang, Z.: Multiple observation types reduce uncertainty in Australia's terrestrial carbon and water cycles, Biogeosciences, 10, 2011-2040, doi:10.5194/bg-10-2011-2013, 2013.

Henderson-Sellers, A., Fischer, M., Aleinov, I., McGuffie, K., Riley, W. J., Schmidt, G. A., Sturm, K., Yoshimura, K., and Irannejad, P.: Stable water isotope simulation by current land-surface schemes: Results of iPILPS phase 1, Global Planet. Change, 51, 34-58, doi:10.1016/j.gloplacha.2006.01.003, 2006.

Herbst, M., Kappen, L., Thamm, F., and Vanselow, R.: Simultaneous measurements of transpiration, soil evaporation and total evaporation in a maize field in northern Germany, J. Exp. Bot., 47, 1957-1962, 1996.

Hoffmann, G., Werner, M., and Heimann, M.: Water isotope module of the ECHAM atmospheric general circulation model: A study on timescales from days to several years, J. Geophys. Res., 103, 16871-16896, 1998.

Horton, R. E.: Rainfall interception, Mon. Weather Rev., 47, 603623, 1919.

Jasechko, S., Sharp, Z. D., Gibson, J. J., Birks, S. J., Yi, Y., and Fawcett, P. J.: Terrestrial water fluxes dominated by transpiration, Nature, 496, 347-350, doi:10.1038/nature11983, 2013.

Keeling, C. D.: The concentration and isotopic abundances of atmospheric carbon dioxide in rural areas, Geochim. Cosmochim. Acta, 13, 322-334, doi:10.1016/0016-7037(58)90033-4, 1958.

Kelliher, F. M., Köstner, B. M. M., Hollinger, D. Y., Byers, J. N., Hunt, J. E., McSeveny, T. M., Meserth, R., Weir, P. L., and Schulze, E.-D.: Evaporation, xylem sap flow, and tree transpiration in a New Zealand broad-leaved forest, Agr. Forest Meteorol., 62, 53-73, 1992. 
Kendall, C. and McDonnell, J. J.: Isotope tracers in catchment hydrology, Elsevier, Amsterdam, 1998.

Kool, D., Agam, N., Lazarovitch, N., Heitman, J. L., Sauer, T. J., and Ben-Gal, A.: A review of approaches for evapotranspiration partitioning, Agr. Forest Meteorol., 184, 56-70, doi:10.1016/j.agrformet.2013.09.003, 2014.

Lai, C.-T., Ehleringer, J. R., Bond, B. J., and Paw U, K. T.: Contributions of evaporation, isotopic non-steady state transpiration and atmospheric mixing on the $\delta^{18} \mathrm{O}$ of water vapour in Pacific Northwest coniferous forests, Plant Cell Environ., 29, 77-94, 2006.

Lawrence, D. M. and Slingo, J. M.: An annual cycle of vegetation in a GCM, Part I: implementation and impact on evaporation, Clim. Dynam., 22, 87-105, doi:10.1007/s00382-003-0366-9, 2004.

Lawrence, D. M., Thornton, P. E., Oleson, K. W., and Bonan, G. B.: The partitioning of evapotranspiration into transpiration, soil evaporation, and canopy interception in a GCM: Impacts on land-atmosphere interaction, J. Hydrometeorol., 8, 862-880, doi:10.1175/JHM596.1, 2007.

Lee, X., Kim, K., and Smith, R.: Temporal variations of the ${ }^{18} \mathrm{O} /{ }^{16} \mathrm{O}$ signal of the whole-canopy transpiration in a temperate forest, Global Biogeochem. Cy., 21, GB3013, doi:10.1029/2006GB002871, 2007.

Lee, D., Kim, J., Lee, K.-S., and Kim, S.: Partitioning of catchment water budget and its implications for ecosystem carbon exchange, Biogeosciences, 7, 1903-1914, doi:10.5194/bg-7-19032010, 2010.

Miguez-Macho, G. and Fan, Y.: The role of groundwater in the Amazon water cycle: 2. Influence on seasonal soil moisture and evapotranspiration, J. Geophys. Res., 117, D15114, doi:10.1029/2012JD017540, 2012.

Miralles, D. G., De Jeu, R. A. M., Gash, J. H., Holmes, T. R. H., and Dolman, A. J.: Magnitude and variability of land evaporation and its components at the global scale, Hydrol. Earth Syst. Sci., 15, 967-981, doi:10.5194/hess-15-967-2011, 2011.

Mitchell, P. J., Veneklaas, E., Lambers, H., and Burgess, S. S. O.: Partitioning of evapotranspiration in a semi-arid eucalypt woodland in south-western Australia, Agr. Forest Meteorol., 149, 2537, 2009.

Monteith, J. L.: Evaporation and surface temperature, Q. J. Roy. Meteorol. Soc., 107, 1-27, 1981.

Mook, W. G.: Environmental Isotopes in the Hydrological CyclePrinciples and Applications, UNESCO-IHP, Paris, 2000.

Moreira, M. Z., Sternberg, L. D. S. L., Martinelli, L. A., Victoria, R. L., Barbosa, E. M., Bonates, L. C. M., and Nepstad, D. C.: Contribution of transpiration to forest ambient vapour based on isotopic measurements, Global Change Biol., 3, 439-450, 1997.

Nagler, P. L., Scott, R. L., Westenburg, C., Cleverly, J. R., Glenn, E. P., and Huete, A. R.: Evapotranspiration on western U.S. River estimated using the enhanced vegetation index from modis and data from eddy covariance and bowen ratio flux towers, Remote Sens. Environ, 97, 337-351, 2005.

Noone, D.: Assessing global model hydrology with simulations from the Stable Water-isotope INtercomparison Group, in: Research Activities in Atmospheric and Oceanic Modeling, Report No. 36, edited by: Cote, J., World Meteorological Organization, Geneva, Switzerland, 4-21, 2007.
Nouri, H., Beecham, S., Kazemi, F., and Hassanli, A. M.: A review of ET measurement techniques for estimating the water requirements of urban landscape vegetation, Urban Water J., 10:4, 247 259, doi:10.1080/1573062X.2012.726360, 2013.

Ogée, J., Cuntz, M., Peylin, P., and Bariac, T.: Non-steady-state, non-uniform transpiration rate and leaf anatomy effects on the progressive stable isotope enrichment of leaf water along monocot leaves, Plant Cell Environ., 30, 367-387, 2007.

Oleson, K. W., Dai, Y., Bonan, G., Dickinson, R. E., Dirmeyer, P. A., Hoffman, F., Houser, P., Levis, S., Niu, G.-Y., Thornton, P., Vertenstein, Z., Yang, Z.-L., and Zeng, X.: Technical description of the community land model (CLM), NCAR Tech. Note NCAR/TN-461+STR, Boulder, Colorado, 174 pp., doi:10.5065/D6N877R0, 2004.

Priestly, C. H. B. and Taylor, R. J.: On the assessment of surface heat flux and evaporation using large-scale parameters, Mon. Weather Rev., 100, 81-92, 1972.

Robertson, J. A. and Gazis, C. A.: An oxygen isotope study of seasonal trends in soil water fluxes at two sites along a climate gradient in Washington state (USA), J. Hydrol., 328, 375-387, 2006.

Roupsard, O., Bonnefond, J.-M., Irvine, M., Berbigier, P., Nouvellon, Y., Dauzat, J., Taga, S., Hamel, O., Jourdan, C., Saint-André, L., Mialet-Serra, I., Labouisse, J.-P., Epron, D., Joffre, R., Braconnier, S., Rouzière, A., Navarro, M., and Boullet, J.-P.: Partitioning energy and evapo-trasnpiration above and below a tropical palm canopy, Agr. Forest Meteorol., 139, 252-268, 2006.

Rozanski, K., Sonntag, C., and Münnich, K. O.: Factors controlling stable isotope composition of European precipitation, Tellus, 34, 142-150, 1982.

Schlesinger, W. H. and Jasechko, S.: Transpiration in the global water cycle, Agr. Forest Meteorol., 189-190, 115-117, doi:10.1016/j.agrformet.2014.01.011, 2014.

Seneviratne, S. I., Corti, T., Davin, E. L., Hirschi, M., Jaeger, E. B., Lehner, I., Orlowsky, B., and Teuling, A. J.: Investigating soil moisture-climate interactions in a changing climate: A review, Earth-Sci. Rev., 99, 125-161, doi:10.1016/j.earscirev.2010.02.004, 2010.

Shuttleworth, W. J.: Evaporation, Handbook of Hydrology, edited by: Maidment, D. R., McGraw-Hill, New York, 4.1-4.53, 1993.

Steppe, K., de Pauw, D. J. W., Doody, T. M., and Teskey, R. O.: A comparison of sap flux density using thermal dissipation, heat pulse velocity and heat field deformation methods, Agr. Forest Meteorol., 150, 1046-1056, doi:10.1016/j.agrformet.2010.04.004, 2010.

Sutanto, S. J., Wenninger, J., Coenders-Gerrits, A. M. J., and Uhlenbrook, S.: Partitioning of evaporation into transpiration, soil evaporation and interception: a comparison between isotope measurements and a HYDRUS-1D model, Hydrol. Earth Syst. Sci., 16, 2605-2616, doi:10.5194/hess-16-2605-2012, 2012.

Tang, K. and Feng, X.: The effect of soil hydrology on the oxygen and hydrogen isotopic compositions of plants source water, Earth Planet. Sc. Lett., 185, 355-367, 2001.

Todd, R. W., Evett, S. R., and Howell, T. A.: The Bowen ratioenergy balance method for estimating latent heat flux of irrigated alfalfa evaluated in a semi-arid, advective environment, Agr. Forest Meteorol., 103, 335-348, 2000. 
Tsiko, C. T., Makurira, H., Gerrits, A. M. J., and Savenije, H. H. G.: Measuring forest floor and canopy interception in a savannah ecosystem, Phys. Chem. Earth, 47-48, 122-127, doi:10.1016/j.pce.2011.06.009, 2012.

Wang, L., Caylor, K. K., Villegas, J. C., Barron-Gafford, G. A., Breshears, D. D., and Huxman, T. E.: Partitioning evapotranspiration across gradients of woody plant cover: Assessment of a stable isotope technique, Geophys. Res. Lett., 37, L09401, doi:10.1029/2010GL043228, 2010.

Wang, L., Good, S. P., Caylor, K. K., and Cernusak, L. A.: Direct quantification of leaf transpiration isotopic composition, Agr. Forest Meteorol., 154-155, 127-135, 2012a.

Wang, L., D’Odorico, P., Evans, J. P., Eldridge, D. J., McCabe, M. F., Caylor, K. K., and King, E. G.: Dryland ecohydrology and climate change: critical issues and technical advances, Hydrol. Earth Syst. Sci., 16, 2585-2603, doi:10.5194/hess-16-25852012, 2012b.

Wang, X.-F. and Yakir, D.: Using stable isotopes of water in evapotranspiration studies, Hydrol. Process., 14, 1407-1421, 2000.

Welp, L. R., Lee, X., Kim, K., Griffis, T. J., Billmark, K. A., and Baker, J. M.: $\delta^{18} \mathrm{O}$ of water vapour, evapotranspiration and the sites of leaf water evaporation in a soybean canopy, Plant Cell Environ., 31, 1214-1228, doi:10.1111/j.13653040.2008.01826.x, 2008.

Wenninger, J., Beza, D. T., and Uhlenbrook, S.: Experimental investigations of water fluxes within the soil-vegetation-atmosphere system: stable isotope mass-balance approach to partition evaporation and transpiration, Phys. Chem. Earth, 35, 565-570, doi:10.1016/j.pce.2010.07.016, 2010.
Williams, D. G., Cable, W., Hultine, K., Hoedjes, J. C. B., Yepez, E. A., Simonneaux, V., Er-Raki, S., Boulet, G., de Bruin, H. A. R., Chehbouni, A., Hartogensis, O. K., and Timouk, F.: Evapotranspiration components determined by stable isotope, sap flow and eddy covariance techniques, Agr. Forest Meteorol., 125, 241258, 2004.

Worden, J., Kulawik, S., Frankenberg, C., Payne, V., Bowman, K., Cady-Peirara, K., Wecht, K., Lee, J.-E., and Noone, D.: Profiles of $\mathrm{CH}_{4}, \mathrm{HDO}, \mathrm{H}_{2} \mathrm{O}$, and $\mathrm{N}_{2} \mathrm{O}$ with improved lower tropospheric vertical resolution from Aura TES radiances, Atmos. Meas. Tech., 5, 397-411, doi:10.5194/amt-5-397-2012, 2012.

Xu, Z., Yang, H., Liu, F., An, S., Cui, J., Wang, Z., and Liu, S.: Partitioning evapotranspiration flux components in a subalpine shrubland based on stable isotopic measurements, Bot. Stud., 49, 351-361, 2008.

Yepez, E. A., Williams, D. G., Scott, R. L., and Lin, G.: Partitioning overstory and understory evapotranspiration in a semiarid savanna woodland from the isotopic composition of water vapor, Agr. Forest Meteorol., 119, 53-68, 2003.

Yepez, E. A., Huxman, T. E., Ignace, D. D., English, N. B., Weltzin, J. F., Castellanos, A. E., and Williams, D. G.: Dynamic of transpiration and evaporation following a moisture pulse in semiarid grassland: A chamber-based isotope method for partitioning flux components, Agr. Forest Meteorol., 132, 359-376, 2005.

Zhang, S., Wen, X., Wang, J., Yu, G., and Sun, X.: The use of stable isotopes to partition evapotranspiration fluxes into evaporation and transpiration, Acta Ecol. Sin., 30, 201-209, doi:10.1016/j.chnaes.2010.06.003, 2010.

Zhang, Y., Shen, Y., Sun, H., and Gates, J. B.: Evapotranspiration and its partitioning in an irrigated winter wheat field: A combined isotopic and micrometeorologic approach, J. Hydrol., 408, 203211, 2011. 